\title{
Pengaruh Pembangunan Infrastruktur Jalan Terhadap Penataan Kawasan Kumuh Pesisir Kota Tarakan
}

\author{
Hendra Julianto, Noptri Jumario \\ Jurusan Teknik Sipil,Universitas Kaltara,Tanjung Selor \\ E-mail : hendra.julianto@gmail.com,E-mail :noptri.jumario@gmail.com
}

\begin{abstract}
ABSTRAK
Begitu banyak persoalan di kawasan kumuh pesisir Kota Tarakan, disisi lain, berbagai upaya telah dilakukan untuk melakukan penataan kawasan pesisir, akan tetapi belum berhasil. Penataan maksimal hanya bisa dilakukan setelah terjadinya kebakaran dengan konsep land consolidation (LC), Pemukiman disekitar lokasi kebakaranpun yang tadinya tampak kumuh ikut berbenah dengan melakukan penimbunan dan melakukan renovasi sendiri karena mudahnya akses jalan disekitar lokasi kebakaran tersebut. Berdasarkan hal tersebut, pembukaan akses dengan pembangunan infrastuktur jalan merupakan salah satu solusi untuk melakukan pembenahan di kawasan kumuh pesisir.

Penelitian ini bertujuan untuk menjelaskan pengaruh pembangunan infrastruktur jalan terhadap penataan kawasan kumuh pesisir Kota Tarakan. Penelitian ini menggunakan metode analisis regresi linear sederhana, koefisien korelasi, koefisien diterminisa dan uji kelayakan model (uji F). Sementara variabel indikator pembangunan infrastruktur jalan terdiri dari: peningkatan kualitas jalan, pelebaran jalan, pembangunan jalan baru, pembangunan jembatan, terbukanya akses jalan sedangkan variabel indicator penataan kawasan kumuh terdiri dari: kondisi bangunan gedung, kondisi jalan lingkungan, kondisi penyediaan air minum, kondisi drainase linkungan, kondisi pengelolaan air limbah, kondisi pengelolaan persampahan, kondisi proteksi kebakaran. Hasil penelitian menunjukkan bahwa. terdapat pengaruh positif variabel pembangunan infrastruktur jalan terhadap penataan kawasan kumuh pesisir tetapi tidak signifikan; terdapat hubungan yang rendah antara variabel pembangunan infrastruktur jalan dengan variabel penataan kawasn kumuh yaitu sebesar 17,6\%; Terdapat pengaruh sebesar 3\% variabel pembangunan infrastruktur jalan terhadap variabel penataan kawasn kumuh, sedangkan sisanya yaitu sebesar 97\% dipengaruhi oleh variabel-variabel lainnya yang tidak diteliti dalam penelitian ini.
\end{abstract}

\section{Kata Kunci}

Pengaruh, Infrastruktur Jalan, Penataan Kawasan Kumuh

\section{PENDAHULUAN}

\subsection{Latar Belakang}

Kawasan kumuh merupakan masalah yang dihadapi oleh hampir semua kota-kota besar di Indonesia bahkan kota-kota besar di negara berkembang lainnya. Menurut data Kementerian Pekerjaan Umum dan Perumahan Rakyat (PUPR), jumlah kawasan kumuh pada seluruh kota di Indonesia mencapai 38.431 hektar, dimana 23.473 hektar berada di wilayah perkotaan dan 11.957 hektar berada di wilayah pedesaaan. Sebagai kota pulau, kawasan kumuh juga terdapat di Kota Tarakan. Berdasarkan Surat Keputusan Walikota Tarakan, kawasan kumuh di kota Tarakan seluas kurang lebih 33,4 hektar yang tersebar pada 4 Kelurahan,
Kelurahan Selumit, Kelurahan Selumit Pantai, Kelurahan Gunung Lingkas dan Kelurahan Sebengkok

Beberapa persoalan terjadi di kawasan kumuh pesisir Kota Tarakan, yaitu mulai dari permukiman di sekitar pantai yang cenderung tidak teratur dan rawan kebakaran; tertutupnya akses publik ke arah laut/sungai, bahkan cenderung mengintervensi hutan mangrove; kurangnya prasarana permukiman seperti penerangan jalan (PJU), air bersih, pengolahan air limbah; sampah berserakan di bawah kolong rumah; hingga minimnya akses jalan lingkungan. Disisi lain, berbagai upaya telah dilakukan untuk melakukan penataan kawasan pesisir yaitu dengan berbagai program serta kebijakan termasuk adanya 
rencana untuk melakukan relokasi, akan tetapi tidak dapat dilaksanakan karena persoalan sosial serta membutuhkan biaya yang sangat besar sekali.

Penataan maksimal hanya bisa dilakukan setelah terjadinya kebakaran dengan konsep land consolidation (LC), dimana penataannya terlebih dahulu mengurug seluruh lokasi ex-kebakaran untuk kemudian selanjutnya dilakukan penataan ulang agar menjadi sebuah kawasan permukiman yang layak. Pemukiman disekitar lokasi kebakaranpun yang tadinya tampak kumuh ikut berbenah dengan melakukan penimbunan dan melakukan renovasi sendiri karena mudahnya akses jalan disekitar lokasi kebakaran tersebut.

Berdasarkan hal tersebut, pembukaan akses dengan pembangunan infrastuktur jalan merupakan salah satu solusi untuk melakukan pembenahan di kawasan kumuh pesisir. Pembangunan infrastruktur jalan dapat dilakukan dengan mengganti seluruh jembatan kayu yang sudah di makan usia dengan konstruksi terbuat dari beton, menambah lebar minimal untuk mengantisipasi bila terjadi musibah kebakaran, menambah pembangunan jalan utama menuju laut berdasarkan kondisi existing serta menambah akses jalan disepanjang pesisir. Diharapkan dengan adanya pembangunan infrastruktur jalan akan memudahkan untuk melakukan penataan kawasan kumuh pesisir. Dalam penelitian ini akan dibahas mengenai pengaruh pembangunan infrastuktur jalan terhadap penataan kawasan kumuh pesisir di Kota Tarakan.

\subsection{Rumusan Masalah}

Berdasarkan latar belakang tersebut dapat dirumuskan permaslahan sebagai berikut:

1. Apakah terdapat pengaruh pembangunan infrastruktur jalan terhadap penataan kawasan kumuh pesisir Kota Tarakan?

2. Bagaimana hubungan pembangunan infrastruktur jalan dengan penataan kawasan kumuh pesisir Kota Tarakan?

3. Seberapa besar pengaruh pembangunan infrastruktur terhadap penataan kawasan kumuh pesisir Kota Tarakan?

\subsection{Maksud dan Tujuan Penelitian}

Adapun maksud dan tujuan penelitian ini, yaitu:

1. Untuk mengetahui pengaruh pembangunan infranstruktur jalan terhadap penataan kawasan kumuh pesisir Kota Tarakan.
2. Untuk mengetahui hubungan pembangunan infranstruktur jalan dengan penataan kawasan kumuh pesisir Kota Tarakan.

3. Untuk mengetahui seberapa besar pengaruh infrastruktur jalan terhadap penataan kawasan kumuh pesisir Kota Tarakan.

\subsection{Manfaat Penelitian}

Hasil penelitian ini diharapkan dapat bermanfaat sebagai masukan kepada Pemerintah dalam menyusun kebijakan perencanaan pembangunan terutama dalam bidang infrastruktur jalan guna meningkatkan kualitas lingkungan kawasan kumuh pesisir. Selain itu, hasil penelitian ini diharapkan bisa menjadi salah satu studi empiris yang dapat memperkaya khasanah ilmu pengetahuan.

\section{TINJAUAN PUSTAKA}

\subsection{Infrastruktur Jalan}

Infrastruktur Jalan adalah suatu prasarana trasnportasi darat yang meliputi segala bagian jalan, termasuk bangunan pelengkap dan perlengkapannya yang diperuntukkan bagi lalu lintas yang berada pada permukaan tanah, dibawah permukaan tanah dan/atau air,serta diataspermukaan air, kecuali jalan kereta api, jalan lori, dan jalan kabel.

Adanya jalan yang baik merupakan persyaratan dasar yang harus dipenuhi untuk mendukung pertumbuhan suatu daerah perkotaan. Jalan juga bertujuan untuk menunjang fungsi kota sebagai pusat pertumbuhan dan mendorong pemerataan pembangunan di dalamkota serta kaitan dengan daerah belakangnya (hinterland)[1].

Jalan memiliki tujuan dan fungsi bagi perekonomian suatu wilayah. Tujuan dan fungsi tersebut, antara lain :

1. Dapat membuka akses atau jalan masuk dari suatu wilayah ke wilayah lain, yang disebut sebagai fungsi land acces. Fungsi ini sangat penting untuk meningkatkan PDRB dan mengurangi daerah yang tertinggal.

2. Jalan berfungsi untuk pelayanan masyarakat setempat (community servicefunction). Pada fungsi ini jalan dapat memberikan jasa-jasanya dalam proses pendistribusian produk, pemasaran ataupun kegiatan-kegiatan masyarakat dan ekonomi lainnya.

3. Jalan dapat memberikan pelayanan bagi angkutan masyarakat jarak jauh dan antar kota atau wilayah, yang berfungsi sebagai 
interchange community andlong distance transportation. Fungsi jalan ini penting bagi wilayah negara yang luas karena semakin berkembangnya teknologi kendaraan bermotor khususnya angkutan jalan jauh.

\subsection{Kawasan Kumuh}

Kawasan kumuh adalah kawasan dimana rumah dan kondisi hunian masyarakat di kawasan tersebut sangat buruk. Rumah maupun sarana dan prasarana yang ada tidak sesuai dengan standar yang berlaku, baik standar kebutuhan, kepadatan bangunan, persyaratan rumah sehat, kebutuhan sarana air bersih, sanitasi maupun persyaratan kelengkapan prasarana jalan,ruang terbuka, serta kelengkapan fasilitas sosial lainnya.

Ciri-ciri permukiman kumuh, seperti yang diungkapkan oleh Suparlan (1997)[2] adalah:

1. Fasilitas umum yang kondisinya kurang atau tidak memadai.

2. Kondisi hunian rumah dan permukiman serta penggunaan ruang-ruangnya mencerminkan penghuninya yang kurang mampu atau miskin.

3. Adanya tingkat frekuensi dan kepadatan volume yang tinggi dalam penggunaan ruangruang yang ada di permukiman kumuh sehingga mencerminkan adanya kesemrawutan tata ruang dan ketidakberdayaan ekonomi penghuninya.

4. Permukiman kumuh merupakan suatu satuansatuan komuniti yang hidup secara tersendiri dengan batas-batas kebudayaan dan sosial yang jelas, yaitu terwujud sebagai:

a. Sebuah komuniti tunggal,berada di tanah milik negara, dan karena itu dapat digolongkan sebagai hunian liar.

b. Satuan komuniti tunggal yang merupakan bagian dari sebuah RT atau sebuah RW.

c. Sebuah satuan komuniti tunggal yang terwujud sebagai sebuah RT atau RW atau bahkan terwujud sebagai sebuah Kelurahan dan bukan hunian liar.

5. Penghuni permukiman kumuh secara sosial dan ekonomi tidak homogen, warganya mempunyai matapencaharian dan tingkat kepadatan yang beranekaragam, begitu juga asal muasalnya. Dalam masyarakat permukiman kumuh juga dikenal adanya pelapisan sosial berdasarkan atas kemampuan ekonomi mereka yang berbeda-beda tersebut.

6. Sebagian besar penghuni permukiman kumuh adalah mereka yang bekerja di sektor informal atau mempunyai mata pencaharian tambahan di sektor informil.

\section{METODE PENELITIAN}

\subsection{Lingkup Kegiatan}

Penelitian ini dilaksanakan di Kota Tarakan tepatnya di kelurahan Selumit Pantai. Secara geografis wilayah Kota Tarakan berada antara $117^{\circ} 34^{\prime}-117^{\circ} 38^{\prime}$ Bujur Timur dan $3^{\circ} 19^{\prime}-3^{\circ} 20^{\prime}$ Lintang Utara. Luas Wilayah Kota Tarakan menurut kecamatan dapat dilihat pada table berikut:

Tabel 3.1 Luas Wilayah Kota Tarakan menurut Kecamatan

\begin{tabular}{|c|c|c|c|c|}
\hline \multirow[t]{2}{*}{ No } & \multirow[t]{2}{*}{ Kecamatan } & \multicolumn{2}{|c|}{$\begin{array}{ll}\text { Luas } & \text { Wilayah } \\
(\mathrm{m} 2) & \end{array}$} & \multirow[t]{2}{*}{ Total } \\
\hline & & Daratan & Lautan & \\
\hline 1 & $\begin{array}{l}\text { Tarakan } \\
\text { Timur }\end{array}$ & 58,01 & 299,69 & 357,70 \\
\hline 2 & $\begin{array}{l}\text { Tarakan } \\
\text { Tengah }\end{array}$ & 55,54 & 28,46 & 84,00 \\
\hline 3 & $\begin{array}{l}\text { Tarakan } \\
\text { Barat }\end{array}$ & 27,89 & 18,46 & 46,35 \\
\hline 4 & $\begin{array}{l}\text { Tarakan } \\
\text { Utara } \\
\end{array}$ & 109,36 & 59,92 & 169,28 \\
\hline \multicolumn{2}{|c|}{ Jumlah } & 250,80 & 406,53 & 657,33 \\
\hline
\end{tabular}

Sumber: Kantor Pertanahan Kota Tarakan

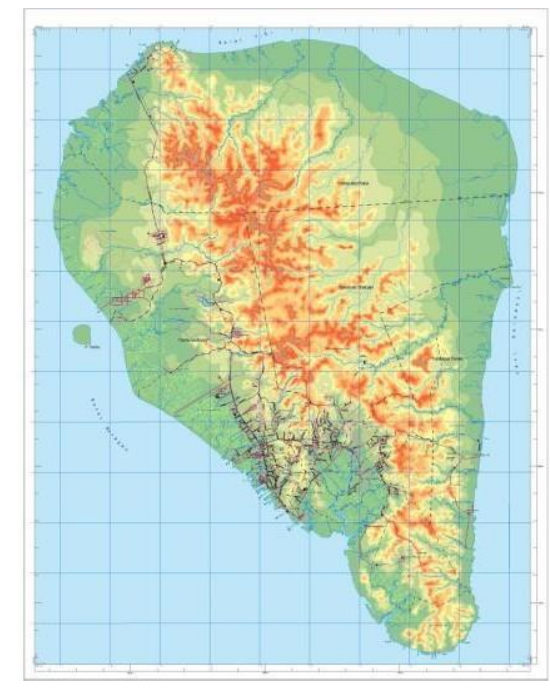

Gambar 3.1 Peta Administrasi Kota Tarakan (Bappeda Kota Tarakan)

Berdasarkan Surat Keputusan Walikota Tarakan nomor 650 /HK-II/69 /2015, menetapkan bahwa lokasi perumahan kumuh dan permukiman kumuh di Kota Tarakan ditetapkan sebagai berikut: 
Tabel 3.2 Lokasi Perumahan Kumuh dan

Pemukiman Kumuh Kota Tarakan

\begin{tabular}{|l|l|l|r|}
\hline \multirow{2}{*}{ No } & \multicolumn{2}{|c|}{ Lokasi } & \multirow{2}{*}{$\begin{array}{c}\text { Luas Kawasan } \\
\left(\mathrm{m}^{2}\right)\end{array}$} \\
\cline { 2 - 3 } & Kecamatan & \multicolumn{1}{|c|}{ Kelurahan } & 250.340 \\
\hline 1 & \multirow{2}{*}{$\begin{array}{l}\text { Tarakan } \\
\text { Tengah }\end{array}$} & Selumit Pantai & 23.400 \\
\cline { 3 - 3 } & & Sebengkok & 12.100 \\
\cline { 3 - 3 } 2 & $\begin{array}{l}\text { Tarakan } \\
\text { Timur }\end{array}$ & Lelumit & 46.700 \\
\hline \multicolumn{3}{|c|}{ Total } \\
\hline
\end{tabular}

\section{Profil Kawasan Kumuh Selumit Pantai}

Kawasan kumuh Selumit Pantai termasuk kategori kumuh berat dengan luasan mencapai 25,04 ha dari luas kawasan sebesar 35,05 ha. Permasalahan utama kawasan kumuh Selumit Pantai menurut laporan RP2KPKP [3], sebagai berikut:

- Rendahnya Kesadaran Masyarakat Mengenai Perilaku Hidup Bersih \& Sehat (PHBS)

- Ketidakberdayaan MBR didalam pemenuhan rumah sehat \& layak huni (Kemiskinan Perkotaan)

- Kawasan Rawan Banjir \& Rawan Rob

- Sanitasi Beresiko Tinggi

- Ketidakteraturan bangunan \& Kepadatan bangunan tinggi

- Tingginya RTLH

- Banyaknya masyarakat menempati bangunan milik orang lain

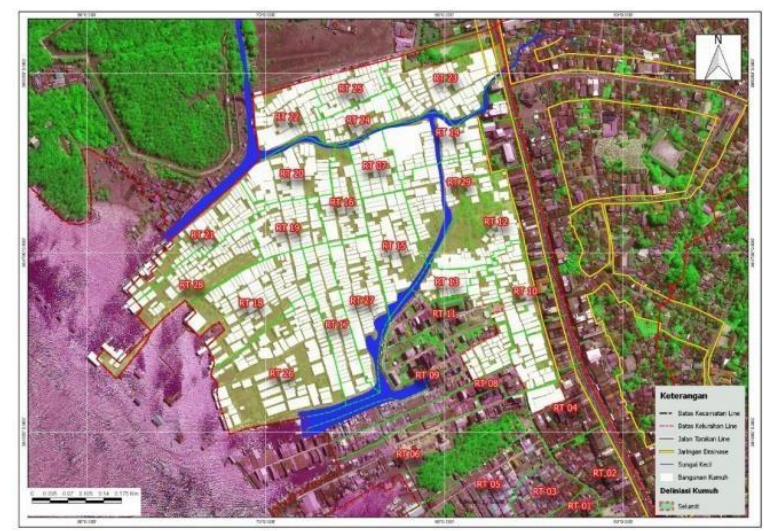

Gambar 3.2 Peta Kawasan Kumuh Selumit Pantai Kota Tarakan (RP2KP Kota Tarakan)

\subsection{Desain Penelitian}

Dalam penelitian ini akan menggunakan metode deskriptif dengan pendekatan kuantitatif guna mendapatkan jawaban hipotesis yang telah diajukan serta dapat mewujudkan tujuan penelitian sesuai dengan yang telah ditetapkan. Penelitian ini dilakukan dengan menggunakan analisa non statistik untuk menganalisis data kualitatif, yaitu dengan membaca table-tabel, grafik/angka-angka yang tersedia kemudian dilakukan uraian dan penafsiran.

Desain penelitian ini mengambil suatu pendekatan dalam bentuk pengujian pengaruh antara variabel. Penelitian dan penggunaan desain ini dengan tujuan untuk mempermudah pengukuran hubungan antara variabel bebas dan variabel terikat. Dalam hal ini pengaruh Pembangunan Infrastruktur Jalan terhadap Penataan Kawasan Kumuh Pesisir Kota Tarakan.

\subsection{Variabel Penelitian}

Ruang lingkup dalam penelitian ini mengunakan variabel pembangunan infrastruktur jalan sebagai variabel bebas. Sedangkan yang menjadi variabel terikat adalah penataan kawasan kumuh.

Dengan demikian, maka penelitian ini dapat diilustrasikan sebagai berikut:

Keterangan:

$$
\begin{aligned}
& \mathrm{X} \quad=\text { Pembangunan Infrastruktur Jalan } \\
& \mathrm{Y} \quad=\text { Penataan kawasan kumuh Pesisir } \\
& \text { Pxy = Menunjukkan seberapa besar pengaruh (X) } \\
& \text { terhadap (Y) }
\end{aligned}
$$

\section{Deskripsi Instrumen Penelitian}

\section{Variabel Pembangunan Infrastruktur Jalan}

a) Definisi Konseptual Pembangunan Infrastruktur Jalan

Pembangunan infrastruktur jalan merupakan salah satu program utama pemerintah sebagai struktur dasar dalam penataan elemen lingkungan. Dengan adanya sarana transportasi darat, maka pertumbuhan ekonomi meningkat, serta peningkatan akses terhadap pelayanan masyarakat apat berjalan dengan lancar dan cepat.

b) Definisi Operasional Pembangunan Infrastruktur Jalan

Skor pembangunan infrastruktur jalan yang diperoleh dari 30 responden yang diukur dengan menggunakan instrumen berbentuk skala likert (likert scale) terdiri dari 5 butir pertanyaan yang ditandai dengan beberapa indikator yaitu: peningkatan kualitas jalan, pelebaran jalan, pembangunan jalan baru, pembangunan jembatan, terbukanya akses jalan. 
c) Kisi-Kisi Instrumen Pembangunan Infrasturktur Jalan

Data penelitian tentang pembangunan infrastruktur jalan yang disusun dangan skala likert (likert scale) dimaksud adalah skor 1 sebagai pembangunan infrastruktur jalan yang terendah dan skor 5 adalah pembangunan infrastruktur jalan yang tertinggi. Kisi-kisi ditampilkan merupakan matriks dari variabel dan indikator serta sebaran butir instrumen.

Dari matriks ini tercatat 5 butir yang digunakan dalam penelitian untuk mendapatkan sejumlah informasi atau data dari responden. Berikut dapat dilihat kisi-kisi variabel pembangunan infrastruktur jalan yang digunakan dalam penelitian ini.

Tabel 3.3 Variabel Pembangunan Infrastruktur Jalan.

\begin{tabular}{|c|c|c|}
\hline Variabel & Indikator & Keterangan \\
\hline \multirow[t]{5}{*}{$\begin{array}{l}\text { Pembangunan } \\
\text { infrastruktur } \\
\text { Jalan }\end{array}$} & $\begin{array}{l}\text { Peningkatan } \\
\text { kualitas jalan }\end{array}$ & $\begin{array}{l}\text { Peningkatan kualitas } \\
\text { jalan } \\
\mathrm{L} 1,2 \mathrm{~m}=2028,33 \mathrm{~m}, \\
\mathrm{~L} 1,5 \mathrm{~m}=2918,72 \mathrm{~m}, \\
\mathrm{~L} 1,8 \mathrm{~m}=269,96 \mathrm{~m}, \\
\mathrm{~L} 2 \mathrm{~m}=878,36 \mathrm{~m}, \\
\mathrm{~L} 3 \mathrm{~m}=489,36 \mathrm{~m}, \\
\mathrm{~L} 4 \mathrm{~m}=2923,04 \mathrm{~m}, \\
\mathrm{~L} 5 \mathrm{~m}=55,34 \mathrm{~m}\end{array}$ \\
\hline & $\begin{array}{l}\text { Pelebaran } \\
\text { Jalan }\end{array}$ & $\begin{array}{l}\text { Pelebaran jalan dari } 1 \mathrm{~m} \\
\text { menjadi } \\
\mathrm{L}=3 \mathrm{~m}(664,73 \mathrm{~m}) \\
\mathrm{L}=4 \mathrm{~m}(2004,04 \mathrm{~m})\end{array}$ \\
\hline & $\begin{array}{l}\text { Pembangunan } \\
\text { jalan baru }\end{array}$ & $\begin{array}{l}\text { Pembangunan baru } \\
\text { jalan lingkungan } \\
\mathrm{L}=3 \mathrm{~m}(664,73 \mathrm{~m}), \\
\mathrm{L}=4 \mathrm{~m}(2004,04 \mathrm{~m})\end{array}$ \\
\hline & $\begin{array}{l}\text { Pembangunan } \\
\text { Jembatan }\end{array}$ & $\begin{array}{l}\text { Pembangunan Jembatan } \\
\text { Tipe } I(L=5 m)=2 \text { unit, } \\
\text { Tipe II }(L=5 m)=1 \text { unit, } \\
\text { Tipe III }(L=2 m)=5 \text { unit }\end{array}$ \\
\hline & $\begin{array}{l}\text { Terbukanya } \\
\text { akses jalan }\end{array}$ & $\begin{array}{l}\text { Terbukanya akses jalan } \\
664,73 \mathrm{~m} \text { dan } 2004,04 \mathrm{~m}\end{array}$ \\
\hline
\end{tabular}

Sumber: hasil analisis dan data sekunder

\section{Variabel Penataan Kawasan Kumuh}

a) Definisi Penataan Kawasan Kumuh

Penataan kawasan kumuh adalah berbagai jenis kegiatan, baik yang mencakup sektor pemerintah maupun masyarakat dan dilaksanakan dalam rangka memperbaiki tingkat kesejahteraan masyarakat.

b) Definisi Operasional Penataan Kawasan Kumuh Skor penataan kawasan kumuh pesisiryang diperoleh dari 30 responden yang diukur dengan instrumen berbentuk skala likert (likert scale) yang terdiri dari 7 butir pernyataan yang ditandai oleh beberapa indikator yaitu: kondisi bangunan gedung, kondisi jalan lingkungan, kondisi penyediaan air minum, kondisi drainase linkungan, kondisi pengelolaan air limbah, kondisi pengelolaan persampahan, kondisi proteksi kebakaran.

c) Kisi-Kisi Instrumen Penataan Kawasan Kumuh Pesisir

Data penelitian tentang penataan kawasan kumuh disusun dengan menggunakan skala 1 sampai skala likert (likert scale) dimaksud adalah skor 1 adalah penataan kawasan kumuh yang terendah dan skor 5 adalah penataan kawasan kumuh yang tertinggi. Kisi-Kisi yang ditampilkan merupakan matriks dari variabel dan indikator serta sebaran butir instrumen.

Dari matriks ini tercatat 7 butir yang digunakan dalam penelitian untuk mendapatkan sejumlah data dan informasi dari responden. Berikut dapat dilihat kisi-kisi instrumen variabel penataan kawasan kumuh yang digunakan dalam penelitian ini.

Tabel 3.4. Variabel Pembangunan Infrastruktur Jalan

\begin{tabular}{|c|c|c|}
\hline Variabel & Indikator & Keterangan \\
\hline \multirow[t]{7}{*}{$\begin{array}{l}\text { Penataan } \\
\text { Kawasan } \\
\text { Kumuh } \\
\text { Pesisir }\end{array}$} & $\begin{array}{l}\text { Kondisi } \\
\text { bangunan } \\
\text { gedung }\end{array}$ & $\begin{array}{l}\text { Jumlah Bangunan = 2.774 Unit } \\
\text { - Jumlah RTLH = 268 Unit } \\
\text { - } 1.712 \text { Unit Bangunan tdk teratur } \\
\text { - } 111 \text { Unit/Ha tingkat kepadatan } \\
\text { - } 1.194 \text { Unit Bangunan tdk sesuai } \\
\end{array}$ \\
\hline & $\begin{array}{l}\text { Kondisi } \\
\text { jalan } \\
\text { lingkungan }\end{array}$ & $\begin{array}{l}\text { Panjang Jalan }=24.320 \mathrm{~m} \\
\text { • } 17.270 \mathrm{~m} \text { tidak sesuai dengan PT } \\
\text { - } 6.298 \text { meter mengalami kerusakan }\end{array}$ \\
\hline & $\begin{array}{l}\text { Kondisi } \\
\text { penyediaan } \\
\text { air minum }\end{array}$ & $\begin{array}{l}\text { Cakupan pelayanan air }=33 \text { Unit RT } \\
\text { - } 2.741 \text { Unit RT tidak dapat akses } \\
\text { - 2.518 Unit RT tidak terpenuhi } \\
\text { kebutuhan air }(601 / \text { org/hari }) \\
\end{array}$ \\
\hline & $\begin{array}{l}\text { Kondisi } \\
\text { drainase } \\
\text { lingkungan }\end{array}$ & $\begin{array}{l}\text { Panjang Drainase }=17.270 \mathrm{M} \\
\text { - } 12,90 \mathrm{Ha} \text { banjir } \\
\text { - } 7,06 \mathrm{Ha} \text { tidak tersedia drainase } \\
\text { - } 621,13 \mathrm{~m} \text { drainase tidak terhubung } \\
\text { - } 649,92 \mathrm{~m} \text { drainase tidak terpelihara } \\
\text { - } 5.925 \mathrm{~m} \text { kontruksi tidak memadai } \\
\end{array}$ \\
\hline & $\begin{array}{l}\text { Kondisi } \\
\text { pengolahan } \\
\text { air limbah }\end{array}$ & $\begin{array}{l}\text { - } 51 \%-75 \% \text { Sistem pengelolaan air } \\
\text { limbah sesuai standar teknis } \\
\text { - } 51 \%-75 \% \text { Prasarana dan sarana } \\
\text { sesuai dengan persyaratan teknis }\end{array}$ \\
\hline & $\begin{array}{l}\text { Kondisi } \\
\text { pengelolaan } \\
\text { sampah }\end{array}$ & $\begin{array}{l}\text { Cakupan Sampah terangkut ke } \\
\text { TPS/TPA = 957 Unit rumah tangga } \\
\text { - } 16,55 \text { Ha Kws tidak dilengkapi } \\
\text { sarana sesuai prasyarat teknis } \\
\text { - } 1.817 \text { Unit RT tidak terlayani } \\
\text { pengangkutan ke TPS/TPA } \\
\text { - } 15,30 \text { Ha Kws tidak terpelihara } \\
\end{array}$ \\
\hline & $\begin{array}{l}\text { Kondisi } \\
\text { proteksi } \\
\text { kebakaran }\end{array}$ & $\begin{array}{l}\text { Jumlah Bangunan }=3051 \text { Unit } \\
\cdot \text { - } 8,14 \text { Ha tidak memiliki proteksi } \\
\text { 11,79 Ha tdk memiliki pasokan air } \\
\text { - } 4.667,04 \text { meter jalan tidak dapat } \\
\text { dilalui mobil pemadam kebakaran }\end{array}$ \\
\hline
\end{tabular}

Sumber: hasil analisis dan data sekunder

\subsection{Populasi dan Sampel Penelitian}

\section{Populasi}

Sugiyono (2011:141) menyatakan bahwa "Populasi adalah wilayah generalisasi yang terdiri dari: Subjek/objek yang mempunyai kualitas dan 
karakteristik tertentu yang ditetapkan oleh peneliti untuk dipelajari dan kemudian ditarik kesimpulan”. Dalam penelitian ini populasi target adalah jumlah penduduk di kwasan kumuh Selumit pantai yang berjumlah 7.631 orang.

\section{Sampel}

Untuk menentukan sampel dari populasi digunakan perhitungan atau acuan tabel yang dikembangkan oleh ahli. Secara umum, untuk penelitian korelasional jumlah sampel minimal untuk memperoleh hasil yang baik adalah 30. Roscoe dalam Sugiyono (2011:90), memberikan acuan umum untuk menentukan sampel yaitu bahwa "Ukuran sampel yang layak dalam penelitian adalah antara 30 sampai dengan 500". Dalam penelitian ini, peneliti tidak menggunakan perhitungan statistic untuk menentukan sampel, akan tetapi menggunakan sampel minimal untuk memperoleh hasil yang baik yaitu 30 sampel.

\subsection{Metode Pengumpulan Data}

Dalam hal ini, data yang dikumpulkan ada dua yaitu data primer berupa kuisioner dan data sekunder yang diperoleh melalui buku, literature dan sumber lainnya. Untuk kuesioner, pengumpulan data dilakukan dengan cara memberi seperangkat pertanyaan untuk dijawabnya. Kuisioner tersebut bersifat kualitatif yang kemudian dikuantitatifkan dengan cara memberi skor (nilai) dengan menggunakan skala likert yaitu sebagai berikut : Sangat setuju diberi nilai 5), Setuju diberi nilai 4, Cukup setuju diberi nilai 3, Tidak setuju diberi nilai 2 dan Sangat tidak setuju diberi nilai 1.

\subsection{Metode Analisis}

Dalam penelitian ini pengujian data dilakukan dengan cara:

\section{Uji Validitas}

Uji validitas digunakan untuk mengukur sah atau tidaknya suatu kuesioner dalam mengukur. Uji validitas dalam penelitian ini menggunakan rumus korelasi Pearson's Product Moment.

Adapun langkah-langkahnya sebagai berikut:

a) Menghitung harga korelasi setiap butir dengan rumus Pearson Product Moment, sebagai berikut:

$$
r_{x y}=\frac{n \sum X_{i} Y_{i}-\left(\sum X_{i}\right)\left(\sum Y_{i}\right)}{\sqrt{\left\{n \sum X_{i}^{2}-\left(\sum X_{i}\right)^{2}\right\}\left\{n \sum Y_{i}^{2}-\left(\sum Y_{i}\right)^{2}\right\}}}
$$

$$
\begin{array}{ll}
\text { Keterangan : } \\
\text { rxy } & =\text { koefisien korelasin } \\
\mathrm{n} & =\text { jumlah responden uji coba } \\
\mathrm{X} & =\text { skor tiap item } \\
\mathrm{Y} & =\text { skor seluruh item responden uji coba }
\end{array}
$$

b) Menghitung harga $t$ hitung dengan rumus sebagai berikut:

$$
t_{\text {hitung }}=\frac{r_{x y} \sqrt{(n-2)}}{\sqrt{\left(1-r_{x y^{2}}\right)}}
$$

Keterangan :

$\mathrm{t}=$ Nilai $\mathrm{t}$ hitung

$\mathrm{n}=$ jumlah responden uji coba

$\mathrm{r}=$ koefisien korelasi hasil $\mathrm{r}$ hitung

c) Mencari t tabel apabila diketahui signifikansi untuk $\alpha=0.05$ dan $\mathrm{dk}=30-2=28$, dengan uji dua pihak

d) Membandingkan t hitung dengan ttabel.Apabila $\mathrm{t}$ hitung lebih besar dari $\mathrm{t}$ tabel $(\mathrm{th}>\mathrm{tt})$ maka butir instrumen tersebut valid, tetapi sebaliknya bila $t$ hitung lebih kecil dari $\mathrm{t}$ tabel $(\mathrm{th}<\mathrm{tt})$ maka instrumen tersebut tidak valid dan tidak dipergunakan dalam penelitian (Nidjo Sandjojo, 2011:130-131)

\section{Uji Reabilitas}

Analisis reliabilitas artinya adalah tingkat kepercayaan hasil suatu pengukuran. Adapun langkah-langkahnya adalah sebagai berikut :

a) Menghitung varians skor tiap-tiap item dengan rumus :

$$
S_{i}=\frac{\sum X_{i}^{2}-\frac{\left(\sum X_{i}\right)^{2}}{N}}{N}
$$

Dimana :

$$
\begin{aligned}
& \mathrm{Si} \quad=\text { Varians skor tiap-tiap item } \\
& \sum \mathrm{Xi} 2=\text { Jumlah kuadrat item Xi } \\
& \left(\sum \mathrm{Xi}\right) 2=\text { Jumlah item Xi dikuadratkan } \\
& \mathrm{N} \quad=\text { Jumlah responden }
\end{aligned}
$$

b) Menjumlahkan varians semua item dengan rumus :

$\sum \mathrm{Si}=\mathrm{S} 1+\mathrm{S} 2+\mathrm{S} 3+\ldots \ldots . . \mathrm{Sn}$

c) Menghitung Varians total dengan rumus :

$$
S_{t}=\frac{\sum X_{t}^{2}-\frac{\left(\sum X_{t}\right)^{2}}{N}}{N}
$$

d) Menghitung nilai Alpha dengan rumus:

$$
r_{11}=\frac{k}{k-1} \times\left\{1-\frac{\sum S_{i}}{S_{t}}\right\}
$$

Bila koefisien reliabilitas telah dihitung, nilai tingkat keandalan Cronbach's Alpha dapat ditunjukan pada tabel berikut ini. 
Tabel 3.4. Variabel Pembangunan Infrastruktur Jalan.

\begin{tabular}{|c|c|}
\hline Nilai Alpha & Tingkat Keandalan \\
\hline $0.0-0.20$ & Kurang Andal \\
\hline$>0.20-0.40$ & Agak Andal \\
\hline$>0.40-0.60$ & Cukup Andal \\
\hline$>0.60-0.80$ & Andal \\
\hline$>0.80-1.00$ & Sangat Andal \\
\hline
\end{tabular}

\section{Uji Normalitas}

Uji normalitas liliefors digunakan bila ukuran sampel (n) lebih kecil dari 30. Jika nilai signifikan lebih dari 0,05 maka data tersebut terdistribusi normal begitu juga sebaliknya. Langkah-langkah uji normalitas data dengan rumus Lilliefors, yaitu:

a) Mengurutkan data dari terkecil ke terbesar

b) Mencari rata-rata, simpangan baku sampel(SD)

c) Mencari nilai $\mathrm{Z}$ score, dengan rumus : $\mathrm{Z}=(\mathrm{Xi}-$ Mean)/SD

d) Menentukan Nilai $\mathrm{Z}$ tabel $\{\mathrm{F}(\mathrm{z})\}$ dengan menggunakan tabel Normal Baku dari $O$ ke $Z$ berdasarkan nilai $Z$ score.

e) Menentukan $\mathrm{S}(\mathrm{z})$ dengan rumus $\mathrm{S}(\mathrm{z})=\mathrm{f}$ kum : $\mathrm{N}$

f) Menghitung harga Lilliefors hitung dengan rumus : $\mathrm{L}_{\mathrm{h}}=|\mathrm{F}(\mathrm{z})-\mathrm{S}(\mathrm{z})|$

g) Mencari nilai Lilliefors terbesar sebagai $L_{\text {hitung }}$

h) Menentukan harga Lillefors tabel $\left(\mathrm{L}_{\mathrm{t}}\right)$ dengan rumus : $(\mathrm{a}, \mathrm{n})$

i) Membuat kesimpulan :

- Jika harga $\mathrm{L}_{\mathrm{h}}<$ harga Lt, maka data berdistribusi normal

- Jika harga $L_{h}>$ harga $L_{t}$, maka data tidak berdistribusi normal

\section{Analisis}

Hasil penyebaran angka masing-masing data diberi skor untuk dihitung dan dianalisa. Teknik untuk menganalisa data yang digunakan dalam penelitian ini adalah teknik dan regresi, yaitu dengan :

- Regresi linier sederhana untuk melihat linearitas hubungan antara variabel $(\mathrm{X})$ dan variabel $(\mathrm{Y})$ dan untuk menentukan kecenderungan kontribusi variabel Pembangunan Infrastruktur Jalan (X) terhadap Penataan Kawasan Kumuh (Y).

- Korelasi sederhana untuk menentukan ada tidaknya hubungan variabel Pembangunan Infrastruktur Jalan (X) terhadap Penataan Kawasan Kumuh (Y).

Adapun langkah-langkah yang harus ditempuh dalam penelitian ini adalah:

a) Untuk mengetahui adanya pengaruh variabel bebas $(\mathrm{X})$ terhadap variabel terikat $(\mathrm{Y})$, maka digunakan regresi linear sederhana, dengan rumus:
Persamaan regresi dirumuskan : $\mathrm{Y}=\mathrm{a}+\mathrm{bX}$

Dimana :

$\mathrm{Y}=$ Variabel terikat yang diproyeksikan

$\mathrm{X}=$ Variabel bebas mempunyai nilai tertentu untuk diprediksikan

$\mathrm{a}=$ Nilai konstanta harga $\mathrm{Y}$ jika $\mathrm{X}=0$

$\mathrm{b}=$ Nilai arah sebagai penentu ramalan

(prediksi) yang menunjukkan nilai peningkatan

$(+)$ atau nilai penurunan (-) variabel $Y$

$$
b=\frac{n \sum X Y-\sum X \sum Y}{n \sum X^{2}-\left(\sum X\right)^{2}} \quad a=\frac{\sum Y-b \sum X}{n}
$$

b) Untuk melihat kekuatan hubungan dengan kolerasi sederhana dengan mengunakan rumus:

$$
r x y=\frac{\mathrm{n} \sum \mathrm{xy}-\left(\sum \mathrm{x}\right)\left(\sum \mathrm{x}\right)}{\sqrt{\left[\mathrm{n} \sum \mathrm{x}-\left(\sum \mathrm{x}\right)^{2}\left(\mathrm{n} \sum \mathrm{y}^{2}-(\mathrm{y})^{2}\right]\right.}}
$$

$$
\begin{aligned}
& \text { Dimana: } \\
& \text { Rxy : Koefesien kolerasi } y \text { dan } x \\
& \sum x^{2} \quad \text { Jumlah kuadrat dari skor } x \\
& \sum x \quad \text { : Jumlah skor } x \\
& \mathrm{n} \sum \mathrm{y}^{2} \\
& \sum \mathrm{y}
\end{aligned}
$$

c) Untuk melihat besarnya pengaruh variabel Pembangunan Infrastruktur Jalan (X) terhadap variabel Penataan kawasan kumuh pesisir $(\mathrm{Y})$ dengan angka $R$ square atau koefesien determinasi, dengan menggunakan rumus:

$\mathrm{KD}=(\mathrm{r} 2)$

d) Dilanjutkan dengan uji signifikan korelasi produk momen dengan Uji (F) dengan mengunakan rumus:

Dimana:

jika $F_{\text {hitung }}<\mathrm{F}_{\text {tabel, }}$ maka $\mathrm{H}_{\mathrm{o}}$ diterima

jika $F_{\text {hitung }}>F_{\text {tabel }}$, maka $\mathrm{H}_{\mathrm{o}}$ ditolak

\section{HASIL DAN PEMBAHASAN}

\subsection{Hasil Uji Validitas}

Berdasarkan hasil uji validitas pada instrument variabel pembangunan insfrastruktur jalan diperoleh hasil sebagai pada table berikut:

Tabel 4.1. Variabel Pembangunan Infrastruktur Jalan.

\begin{tabular}{|c|c|c|c|c|}
\hline Item & rxy & Thitung & $\begin{array}{c}\text { ttabel } \\
\mathbf{( 5 \% , 2 8 )}\end{array}$ & Validitas \\
\hline X1 & 0.454 & 2.697 & 1.701 & Valid \\
\hline X2 & 0.549 & 3.474 & 1.701 & valid \\
\hline X3 & 0.455 & 2.707 & 1.701 & Valid \\
\hline X4 & 0.775 & 6.492 & 1.701 & Valid \\
\hline
\end{tabular}


Dari tabel di atas menunjukkan bahwa $\mathrm{t}$ hitung $>\mathrm{t}$ table maka butir instrumen tersebut valid. Item tertinggi dengan nilai korelasi sebesar 0,775 adalah item 4 . Untuk item terendah dengan nilai sebesar 0.454 adalah item 1 . Sedangkan hasil uji validitas instrumen variabel penataan kawasan kumuh dapat dilihat pada tabel berikut:

Tabel 4.2 Variabel Pembangunan Infrastruktur Jalan.

\begin{tabular}{|c|c|c|c|c|}
\hline Item & rxy & thitung & $\begin{array}{c}\text { ttabel } \\
\mathbf{5 \% , 2 8})\end{array}$ & validitas \\
\hline Y1 & 0.445 & 2.630 & 1.701 & valid \\
\hline Y2 & 0.620 & 4.181 & 1.701 & valid \\
\hline Y3 & 0.340 & 1.913 & 1.701 & valid \\
\hline Y4 & 0.723 & 5.531 & 1.701 & valid \\
\hline Y5 & 0.539 & 3.387 & 1.701 & valid \\
\hline Y6 & 0.608 & 4.051 & 1.701 & valid \\
\hline Y7 & 0.552 & 3.507 & 1.701 & valid \\
\hline
\end{tabular}

Sumber: hasil perhitungan

Dari tabel di atas menunjukkan bahwa $\mathrm{t}$ hitung $>\mathrm{t}$ table, maka butir instrumen tersebut valid. Item tertinggi dengan nilai sebesar 0,723 adalah item 4. Sedangkan item yang terendah dengan nilai sebesar 0.340 adalah item 3 .

\subsection{Hasil Uji Reliabilitas}

Hasil uji reliabilitas pada Tabel 4.3 di atas menunjukkan bahwa cronbach's alpha yang cukup besar yaitu 0.661 , artinya nilai tersebut di atas 0,60 , sehingga dapat disimpulkan bahwa semua itemitem pengukur variabel $\mathrm{X}$ dari kuesioner adalah reliable dengan tingkat andal

Tabel 4.3 Uji Reliabilitas Variabel Pembangunan
Infrastruktur Jalan
\begin{tabular}{|l|l|l|}
\hline$\sum$ Var & Var total & Alpha \\
\hline 2.201 & 4.368 & 0.661 \\
\hline Sumber: hasil perhitungan
\end{tabular}

Hasil uji reliabilitas pada tabel di atas menunjukkan bahwa nilai cronbach's alpha yang cukup besar yaitu 0.621 , artinya nilai tersebut berada di atas 0,60, sehingga dapat disimpulkan bahwa semua item-item pengukur variabel $\mathrm{Y}$ dari kuesioner adalah reliable dengan tingkat andal.

Tabel 4.4 Uji Realibilitas Variabel Penataan Kawasan Kumuh.

\begin{tabular}{|l|l|l|}
\hline$\sum$ Var & Var total & Alpha \\
\hline 5.078 & 10.868 & 0.621 \\
\hline \multicolumn{2}{|l}{ Sumber: hasil perhitungan } \\
\hline
\end{tabular}

\subsection{Hasil Uji Normalitas}

Berdasarkan tabel hasil perhitungan diperoleh harga Lh untuk variabel pembangunan infrastruktur sebesar $=0,010$ dan untuk variabel penataan kawasan kumuh sebesar $=0.0818$ Kemudian diperoleh bahwa harga $\mathrm{L}$ tabel ( $\mathrm{Lt}$ ) dengan $\mathrm{a}=95 \%$ dan $\mathrm{n}=30$ adalah Lt $(0,05 ; 30)=0,161$. Dengan demikian, karena $\mathrm{Lh}=0,010$ dan 0.0818 kurang dari Lt $(0,05 ; 30)=0,137$, maka dapat disimpulkan bahwa data yang di uji berdistribusi normal.

\subsection{Hasil Analisis Regresi Sederhana}

Berdasarkan tabel 4.5 diperoleh persamaan regresi sederhana yaitu $\mathrm{Y}=19.016+0,278 \mathrm{X}$, maka diketahui bahwa:

1. Pembangunan infrastruktur jalan mempunyai pengaruh positif (koefisien regresi $(b)=0,278$ ) terhadap penataan kawasan kumuh, artinya jika pembangunan infrastruktur jalan meningkat, maka penataan kawasan juga akan semakin meningkat;

2. Nilai konstanta adalah sebesar 19,016, artinya jika pembangunan infrastruktur jalan tidak berjalan atau sama dengan nol, maka penataan kawasan kumuh adalah sebesar 19,016 dengan asumsi variabel-variabel lain yang dapat mempengaruhi dianggap tetap.

Tabel 4.5 Variabel Pembangunan Infrastruktur Jalan.
\begin{tabular}{|l|l|l|}
\hline & Intercept & X Variabel 1 \\
\hline Coefficients & 19.01579 & 0.277822 \\
\hline Standard Error & 5.928381 & 0.293415 \\
\hline t Stat & 3.207585 & 0.946856 \\
\hline P-value & 0.00334 & 0.351812 \\
\hline
\end{tabular}

\subsection{Hasil Uji Koefisien korelasi (r)}

Dari hasil analisis korelasi ® didapat korelasi antara pembangunan infrastruktur dengan penataan kawasn kumuh adalah 0,176 . Hal ini menunujukkan bahwa terjadi hubungan yang rendah antara keduanya. Sedangkan arah hubungan adalah positif karena nilai $r$ positif, berarti semakin meningkat pembangunan jalan maka akan semakin meningkat penataan kawasan kumuh. 
Tabel 4.6 Variabel Pembangunan Infrastruktur Jalan.

\begin{tabular}{|l|l|}
\hline \multicolumn{2}{|l|}{ Regression Statistics } \\
\hline Multiple R & 0.176141 \\
\hline R Square & 0.031026 \\
\hline Regression Statistics \\
\hline Adjusted R Square & -0.00358 \\
\hline Standard Error & 3.302708 \\
\hline Observations & 30 \\
\hline Sumber: hasil analisis
\end{tabular}

\subsection{Hasil Uji Koefisien Determinasi $\left(\mathbf{R}^{2}\right)$}

Dari hasil uji koefisien determinasi $\left(\mathrm{R}^{2}\right)$ yang diperoleh sebesar 0,031. Hal ini berarti bahwa $3 \%$ penataan kawasan kumuh dipengaruhi oleh variabel pembangunan infrastruktur, sedangkan sisanya yaitu sebesar 97\% dipengaruhi oleh variabel-variabel lainnya yang tidak diteliti dalam penelitian ini.

\subsection{Hasil Uji Keayakan Uji F}

Dari tabel 4.7 dapat dilihat nilai $\mathrm{F}$ hitung yaitu 0,896 , sedangkan nilai $\mathrm{F}$ tabel dapat diperoleh dengan menggunakan tabel $\mathrm{F}$ dengan derajat bebas (df) yaitu 1 dan Residual (sisa) yaitu 28 dengan tarap siginifikan 0,05 , sehingga diperoleh nilai $F$ tabel yaitu 3,89. Karena F hitung $(0,401)<\mathrm{F}$ tabel $(3,89)$ maka Ho diterima. Berdasarkan nilai signifikan diperoleh hasil 0.352 , hal ini berarti probabilitas 0,352 lebih besar daripada 0,05 maka Ho diterima. Artinya semua variabel pembangunan infrastruktur jalan secara bersama-sama merupakan penjelas yang signifikan terhadap variabel penataan kawasan kumuh, sehingga tidak ada pengaruh yang signifikan antara variabel pembangunan infrastruktur jalan dengan variabel penataan kawasn kumuh.

Tabel 4.7. Variabel Pembangunan Infrastruktur Jalan.

\begin{tabular}{|l|l|l|}
\hline ANOVA & Regression & Residual \\
\hline Df & 1 & 28 \\
\hline SS & 9.779321 & 305.4207 \\
\hline MS & 9.779321 & 10.90788 \\
\hline F & 0.896537 & \\
\hline Significance F & 0.351812 & \\
\hline \multicolumn{2}{|l}{ Sumber: hasil analisi }
\end{tabular}

\section{KESIMPULAN DAN SARAN}

\subsection{Kesimpulan}

Dari rumusan masalah yang diajukan dan analisis data yang telah dilakukan serta pembahasan yang telah dikemukakan, maka dapat ditarik beberapa kesimpulan sebagai berikut:

terdapat pengaruh positif variabel pembangunan infrastruktur jalan terhadap penataan kawasan kumuh pesisir tetapi tidak signifikan

1. terdapat hubungan yang rendah antara variabel pembangunan infrastruktur jalan dengan variabel penataan kawasn kumuh yaitu sebesar 17,6\%.

2. Terdapat pengaruh sebesar $3 \%$ variabel pembangunan infrastruktur jalan terhadap variabel penataan kawasn kumuh, sedangkan sisanya yaitu sebesar 97\% dipengaruhi oleh variabel-variabel lainnya yang tidak diteliti dalam penelitian ini.

\subsection{Saran}

Berdasarkan kesimpulan yang diperoleh dalam penelitian ini, maka diajukan saran sebagai pelengkap terhadap hasil penelitian yang dapat diberikan sebagai berikut:

1. Bagi peneliti selanjutnya diharapkan dapat meneliti dengan variabel-variabel di luar variabel yang telah diteliti ini agar memperoleh hasil yang lebih bervariatif yang dapat berpengaruh terhadap keputusan pembelian.

2. Disarankan agar tetap meningkatkan pembangunan infrastruktur jalan karena akan meningkatkan penataan kawasan kumuh pesisir juga meskipun tidak signifikan.

\section{DAFTAR PUSTAKA}

[1] Sjafrizal, 2012, Pertumbuhan Ekonomi dan Ketimpangan Regional Wilayah Indonesia Bagian Barat, Jakarta, Jurnal Buletin Prisma Sugiyono. 2011. Metode Penelitian Kuantitatif Kualitatif dan R\&D. Bandung: Alfabeta.

[2] Suparlan, Parsuadi, 1997, Masyarakat dan Kebudayaan Perkotaan. Perspektif Antropologi, UI

[3] Satker Pengembangan Kawasan Permukiman Provinsi Kalimantan Utara, Dirjen CK PUPR, 2016, Pendampingan Penyusunan Rencana Pencegahan Dan Peningkatan Kualitas Permukiman Kumuh Perkotaan (RP2KPKP) Kota Tarakan

[4] Adisasmita, Rahardjo. 2010. Pembangunan Kawasan dan Tata Ruang.Graha Ilmu, Yogyakarta.

[5] http://odexyundo.blogspot.co.id/2009/08/permukimankumuh.html

[6] http://pinterdw.blogspot.co.id/2012/03/permukiman kumuh- pengertian-dan-ciri.html

[7] Kuswartojo, Tjuk,dkk. 1997, Perumahan dan Permukiman di Indonesia. Penerbit ITB, Bandung

[8] Putro, J.D.2011. Penataan Kawasan Kumuh Pinggiran Sungai di Kecamatan Sungai Raya.Jurnal Teknik Sipil Untan. 11:19-34 
[9] Ruhaida.dan Sunarti.2012. Pemberdayaan Masyarakat Dalam Peningkatan Kualitas Permukiman Kumuh Pada Kegiatan PNPM di Kelurahan Muareja Kota Tegal. Jurnal Tenik PWK, 1: 46-65

[10] Santosa, W \& Van Roy, S, 2005, "Korelasi Investasi Infrastruktur Jalan Terhadap Pertumbuhan Ekonomi Regional", Universitas Katolik Parahyangan.

[11] Simposium XII FSTPT, 2009, “ Kajian Dampak Infrastruktur Jalan Terhadap Pembangunan Ekonomi dan Pengembangan Wilayah", Universitas Kristen Petra Surabaya. 